\title{
Effect of Double Planting Density and Smaller Fertilization Rates on Grain Yield of Quality Protein Maize in a Clay-Sandysoil in Mvuazi
}

\author{
Amand Kankolongo Mbuya1, Jean Pierre Tshiabukole Kabongo ${ }^{1 *}$, Gertrude Khonde Pongi1, \\ André Phongo Matondo', Ngoma Nlandu' ${ }^{1}$, Georges Bolimbo Kombozi ${ }^{1}$, \\ Carcy Jadika Tshimbombo¹, Guillaume Badibanga Mulumba'1, Joachim Kasongo Kaboko, \\ Thérèse Tshibuyi Masengu1, Jean Mbuya Nkongolo², Roger Vumilia Kizungu²
}

${ }^{1}$ Programme National Maïs INERA/RDC, Gandajika, DRC

${ }^{2}$ Direction de l'Expérimentation Agricole, Gandajika, DRC

Email: ${ }^{* j p k a b o n 2005 @ g m a i l . c o m ~}$

How to cite this paper: Mbuya, A.K., Kabongo, J.P.T., Pongi, G.K., Matondo, A.P., Nlandu, N., Kombozi, G.B., Tshimbombo, C.J., Mulumba, G.B., Kaboko, J.K., Masengu, T.T., Nkongolo, J.M. and Kizungu, R.V. (2020) Effect of Double Planting Density and Smaller Fertilization Rates on Grain Yield of Quality Protein Maize in a Clay-Sandysoil in Mvuazi. Open Access Library Journal, 7: e6632.

https://doi.org/10.4236/oalib.1106632

Received: July 21, 2020

Accepted: August 25, 2020

Published: August 28, 2020

Copyright $\odot 2020$ by author(s) and Open Access Library Inc.

This work is licensed under the Creative Commons Attribution International License (CC BY 4.0).

http://creativecommons.org/licenses/by/4.0/

\begin{abstract}
To evaluate the effect of seeding density associated with the different rates of mineral fertilizers on the agronomic performance of quality protein maize (QPM), a study was conducted in Mvuazi station during the 2017-2018 cropping season. Three planting densities (40,000; 53,333 and 106,666 plants.ha $\left.{ }^{-1}\right)$ and four mineral fertilizer rates with localized placement, namely: D1: $0 \mathrm{~kg}$ NPK + 0 kg Urea, D2: $100 \mathrm{~kg}$ NPK + $60 \mathrm{~kg}$ Urea, D3: $150 \mathrm{~kg}$ NPK + $90 \mathrm{~kg}$ urea, D4: $300 \mathrm{~kg} \mathrm{NPK}+120 \mathrm{~kg}$ Urea were tested. A split-plot design with three replicates was used and with fertilizer on main plots and plant density on secondary plots. Measures focused on growth and yield parameters. Data analysis showed that the double planting density $\left(106,666\right.$ plants.ha $\left.^{-1}\right)$ resulted in higher grain yield $\left(6.05 \mathrm{t} \cdot \mathrm{ha}^{-1}\right)$ followed by the one of 53,333 plants.ha ${ }^{-1}$ $\left(4.94 \mathrm{t} \cdot \mathrm{ha}^{-1}\right)$ when the highest fertilizer dose (D4) is applied. The two planting densities out-yielded the farmer's planting density by 40 and $27 \%$ respectively at this fertilizer's rate. Under D3 dose, the double planting density recorded the highest yield ( $5.65 \mathrm{t} \cdot \mathrm{ha}^{-1}$ ) while the two others got similar yields (3.74 and $3.68 \mathrm{t} \cdot \mathrm{ha}^{-1}$ respectively for 53,333 and 40,000 , plants $\cdot \mathrm{ha}^{-1}$ ). It is only under D2 and D1 where yields of all planting densities were similar $(2.69,1.91$ and 2.90 t.ha ${ }^{-1}$ for D1; 4.13, 3.44 and $3.02 t \cdot \mathrm{ha}^{-1}$ for D2) for the 106,666, 53,333 and 40,000 plants $\cdot \mathrm{ha}^{-1}$ planting densities respectively. Thus, the double planting density has been found to be recommendable for intensification of maize cultivation in Mvuazi when utilized at D3 or D4 rates with localized placement.
\end{abstract}




\section{Subject Areas}

Agricultural Science

\section{Keywords}

Double Planting Density, Smaller Rates, QPM, INERA, DRC

\section{Introduction}

Maize (Zea mays L.) is an important food and food crop in the world. It is the first most cultivated cereal in the world, followed by wheat and rice. Thus, its production is the highest of all cereals worldwide. Native to Central and Latin America, maize is currently grown successfully in temperate, tropical and subtropical regions. Fifty years ago, maize was the third most important food crop after cassava and plantain. Currently maize is the second most important food crop after cassava in the Democratic Republic of Congo (DRC) [1]. It is the main cereal and has gained importance in recent years. In Kinshasa, for example, the annual consumption (kg/head) of maize grain increased from $2.84 \mathrm{~kg}$ in 1975 to $6.68 \mathrm{~kg}$ in 2000, an increase of $235 \%$ [2].

In the 1950s, world maize production expanded significantly. Forecasts for the coming years still predict a sharp increase in this production, due in particular to the diversification of uses to which maize grains are destined with 200 million tons produced in 1961. World maize production reached about $712 \mathrm{Mt}$. in 2005 [3]. Africa contributed 65.7 million tons or $7.2 \%$ of a total of 885.3 million metric tons of maize worldwide.

Africa's low contribution to maize production is mainly due to the low average yield per unit area, lack of scientific knowledge and adequate practices [4] and low fertilizer use [5].

In the DRC, yields vary from one region to another, but the national average is 0.8 to $1 \mathrm{t} / \mathrm{ha}$. These yields are very low compared with countries such as Italy (9530 kg/ha), Canada (6630 kg/ha), China (4570 kg/ha) and Argentina (5650 $\mathrm{kg} / \mathrm{ha}$ ) [6]. Most western soils in DRC have low organic matter content, low cation exchange capacities (CEC) and depleted plant nutrients resulting in poor crop yields [5].

To increase yield, it is important to apply good cultural practices [7]. Two important practices for increasing yield are improved cropping practices and fertilizer input [8]. Plant density is one of the most important cultural practices determining grain yield [9]. Other studies have shown that seeding density is a key factor in achieving high yield [10] [11]. Several studies have shown the importance of taking seeding and fertilization density into account in order to increase maize productivity [8] [12] [13] [14]. Carlone and Rinsall [15] found that each variety requires specific planting densities and fertilizer doses to achieve a high yield. Shrestha et al., [16] demonstrated that the key component for a high 
yield of corn is nitrogen fertilizer application. This amount of nitrogen applied mainly depends to a large extent on the plant density of the plants/unit of cultivated land area. They furthermore found that higher grain yield can be achieved at an optimal high plant population with enough nutrient specially nitrogen application. Sharma and Gupta [17] reported that under low plant densities, smaller nitrogen rates produced maximum grain yield $(100 \mathrm{~kg} \cdot \mathrm{N} / \mathrm{ha}$ for 40 and 50 thousands plants/ha) while under higher plant densities only maximum amount of nitrogen ( $200 \mathrm{~kg} \cdot \mathrm{N} / \mathrm{ha}$ for 60 and 70 thousands plants/ha) produced maximum yield. A positive interaction between nitrogen and plant density was found and highest yields were recorded with plant densities of 60,000 and 75,000 plants/ha and $\mathrm{N}$ rate of $100-200 \mathrm{~kg} / \mathrm{ha}$. High plant density is also needed to obtain high yield in maize [18]. For the past several decades, grain yield improvement of maize mainly depended upon enhanced tolerance to increased plant density [19] [20] [21] [22]. The yield gain can be attributed mainly to variety improvement and cropping technique innovations, such as increases in plant density and fertilizer application [23]. Cardwell reported that increased plant density contributed up to $21 \%$ of the gain in maize yield in Minnesota from 1930 to 1970 . Wu [24] stated that fertilizer inputs contributed $50 \%$ of the gain in maize yield in China during the period 1985-1994. Thus, the yield superiority of newer over older varieties is attributed to their productivity improvement and their better adaptation to changes in cropping techniques, such as dense cropping and nitrogen $(\mathrm{N})$ fertilization [21] [25]. A gradual increase in plant density has been a vital contributor to Maize yield enhancement worldwide [26] [27] [28]. In addition, [29] indicated that plant populations have increased dramatically in corn production over the past 40 years. To date, Maize producers in Mvuazi are still using low planting densities, varying from 40,000 plants.ha ${ }^{-1}$ (very common) to 53,333 plants.ha ${ }^{-1}$ (the customary high utilized maize plant density in this area). This limits the potential maize productivity. Even though the 53,333 plants $\cdot \mathrm{ha}^{-1}$ density has proved its yield performance over the one of 40,000 plants.ha $^{-1}$, it is still low when compared to those utilized worldwide. Increasing the planting density from 53,333 plants.ha ${ }^{-1}$ to 106,666 plants.ha ${ }^{-1}$ (double planting density) could to a certain extent improve maize producer's productivity. This double planting density has not been tested so far in this area. Furthermore, high planting densities need more fertilizers to compensate competition between thick plants. In fact, the yield and $\mathrm{N}$ use efficiency (NUE) decrease when maize is planted at a lower density because the plants grow to maturity without using all of the available soil $\mathrm{N}$ [30]. However, plants compete for $\mathrm{N}$ at a higher density with decreasing the amount of $\mathrm{N}$ available per plant [31]. However, fertilizers are not always reasonably priced and then not affordable. The use of smaller fertilization rates with localized placement could minimize fertilizers waste and rationalize their use for poor farmers. In fact, when the recommended rates (350 kg NPK 17-17-17 and $120 \mathrm{~kg}$ urea 46\%) are utilized anyhow, in particular the over-application of $\mathrm{N}$ fertilizer, it results in reduced $\mathrm{N}$ use efficiency in maize production. 
The objective of this study was to assess the agronomic performance of a Quality Protein MaizeMudishi-1 variety in a clay-sandy soil underthedouble planting density and smaller mineral fertilization rates with localized placement in Mvuazi.

\section{Materials and Method}

\subsection{Experimental Site, Soil Description and Characterization}

This study was conducted at the Mvuazi Research Station during the 2017-2018 cropping season. Mvuazi is in the Kongo Central province of DRC with longitude $14^{\circ} 54^{\prime} \mathrm{E}$, latitude $5^{\circ} 21^{\prime} \mathrm{S}$ and altitude $470 \mathrm{~m}$. The Mvuazi soil belongs to the Sudano-Guinean climate zone of the AW4 type [32]. This soil is characterized by low organic matter content and low water holding capacity resulting in low nitrogen availability [5]. Mean annual temperatures vary between $24^{\circ} \mathrm{C}$ and $30^{\circ} \mathrm{C}$ with rainfall ranging from 800 to $1200 \mathrm{~mm}$. The climatic data recorded during the experimental period are presented in Table 1 while the selected chemical and physical parameters for soils at experimental site are presented in Table 2.

Table 1. Monthly climatic data during the trial period in Mvuazi.

\begin{tabular}{cccccc}
\hline \multirow{2}{*}{$\begin{array}{c}\text { Environmental } \\
\text { conditions }\end{array}$} & October & November & December & January & Febuary \\
\cline { 2 - 5 } & 70.7 & 249.8 & 290.7 & 160 & 113 \\
Rainfalls (mm) & 5 & 14 & 8 & 6 & 8 \\
Rainy days & 30.1 & 30.7 & 29.9 & 29.7 & 30.8 \\
Temperature max $\left({ }^{\circ} \mathrm{C}\right)$ & 20.8 & 21.2 & 20.9 & 20.7 & 21.8 \\
Temperature min $\left({ }^{\circ} \mathrm{C}\right)$ & 75.4 & 77.7 & 81.3 & 81.2 & 82.3 \\
\hline
\end{tabular}

Table 2. Selected chemical and physical parameters for soils at experimental site.

\begin{tabular}{|c|c|c|c|c|c|c|c|c|c|}
\hline $\begin{array}{l}\text { Parameters } \\
\text { (unit) }\end{array}$ & Soil pH & $\mathrm{P} 1$ (ppm) & $\mathrm{K}(\mathrm{ppm})$ & $\mathrm{Ca}(\mathrm{ppm})$ & $\mathrm{Mg}(\mathrm{ppm})$ & $\mathrm{Mn}(\mathrm{ppm})$ & $\mathrm{S}(\mathrm{ppm})$ & $\mathrm{Cu}(\mathrm{ppm})$ & $B(p p m)$ \\
\hline Guide Low & 6.00 & 30 & 268 & 1651 & 165 & 100 & 20 & 2.00 & 1.00 \\
\hline Guide high & 7.00 & 100 & 537 & 2064 & 264 & 250 & 200 & 10.00 & 2.00 \\
\hline $\begin{array}{l}\text { Parameters } \\
\text { (unit) }\end{array}$ & $\mathrm{Zn}(\mathrm{ppm})$ & $\mathrm{Na}(\mathrm{ppm})$ & $\mathrm{Fe}(\mathrm{ppm})$ & $\begin{array}{c}\text { CEC } \\
(\mathrm{meq} / 100 \mathrm{~g})\end{array}$ & $\begin{array}{c}\text { OC } \\
(\mathrm{meq} / 100 \mathrm{~g})\end{array}$ & Silt (\%) & Sand (\%) & Clay (\%) & $\mathrm{N}(\%)$ \\
\hline Results & 7.98 & 47 & 194 & 13.76 & 4.07 & 13 & 49 & 39 & 0.21 \\
\hline Guide Low & 4.00 & 0 & 150 & 15.00 & & 30 & 30 & 20 & 0.20 \\
\hline Guide high & 20.00 & 158 & 350 & 30.00 & & 50 & 55 & 55 & 0.50 \\
\hline
\end{tabular}




\subsection{Plant Material}

In this study, seeds of the quality protein maize variety, Mudishi-1 were used. Mudishi-1 variety developed by INERA Gandajika's National maize Program is the most cultivated in the savannah of southwestern of DRC. It is preferred for its yield potential of 4 to $6 \mathrm{t} / \mathrm{ha}$ [33] and its high protein quality [34].

\subsection{Experimental Design}

The trial was carried out since $7^{\text {th }}$ November 2017. A split-plot design with three replicates was used. Four fertilizers rates (main plots) and three planting densities (secondary plots) were set as follows:

\section{Planting densities}

$1 \mathrm{~m} \times 1 \mathrm{~m}$ with four grains per hill, or 40,000 plants.ha ${ }^{-1}$ (farmer's density)

$0.75 \mathrm{~m} \times 0.50 \mathrm{~m}$ with 2 grains per hill, or 53,333 plant $\cdot \mathrm{ha}^{-1}$

$0.75 \mathrm{~m} \times 0.25 \mathrm{~m}$ with 2 grains per hill, or 106,666 plants.ha ${ }^{-1}$ (double planting density)

\section{Fertilizers rates}

D1: $0 \mathrm{~kg} \mathrm{NPK}+0 \mathrm{~kg}$ Urea

D2: $100 \mathrm{~kg} \mathrm{NPK}+60 \mathrm{~kg}$ Urea

D3: $150 \mathrm{~kg} \mathrm{NPK}+90 \mathrm{~kg}$ urea

D4: $300 \mathrm{~kg} \mathrm{NPK}+120 \mathrm{~kg}$ Urea

Before planting, the land was ploughed and harrowed and then partitioned into experimental units sized at $3 \mathrm{~m} \times 5 \mathrm{~m}$. Mineral fertilizer NPK (12-24-12) was applied at planting as basal application while urea (46\%) was applied in two halves at 15 and 30 days after sowing as top dressing application. The fertilization method used was the application of smaller rates of the required amounts with localized placement as shown in Figure 1. Three manual weedings were done at 2, 4 and 10 weeks after sowing to clean the trial.

\subsection{Data Collection}

The following data were collected from the two middle rows of each plot: emergence rate, collar diameter, plant height, plant aspect, days to $50 \%$ flowering (pollen), harvest rate, ear length, ear diameter, ear aspect and yield. The emergence rate was determined by the ratio of number of emerged plants/number of
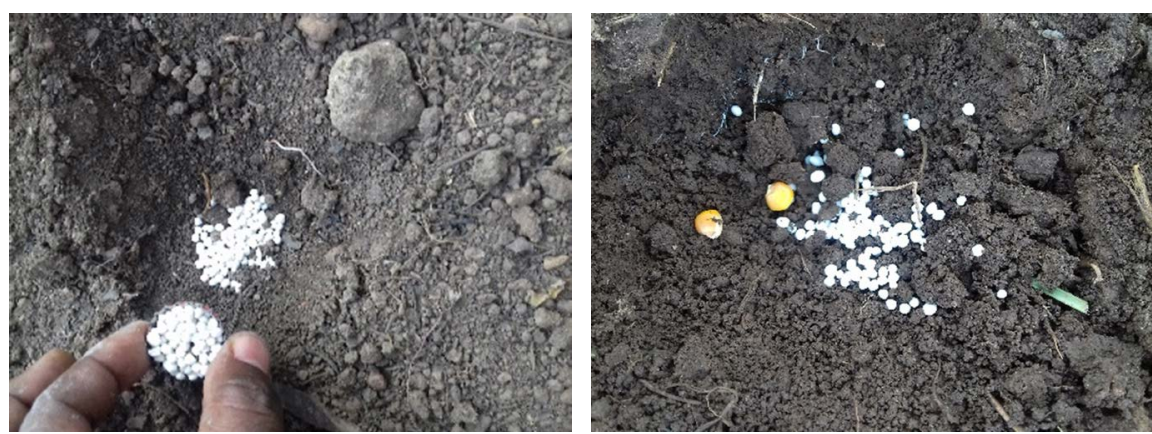

Figure 1. Micro dosing and localized placement method used during seeding. 
seeds sown by 100. Collar diameter was measured with calipers. Plants height was measured using a measuring tape. Days to $50 \%$ flowering were determined by the number of days from the sowing date to the tassels emergence. Plant aspect was measured on the basis of a ratings 1 to 5 ( 1 = excellent, $2=$ very good, 3 $=$ good, $4=$ fair and $5=$ poor). Harvest rate was calculated on the basis of the number of harvested plants/number of plants in the plot. Ears diameter and ear length were measured with calipers and measuring tape respectively. Ear aspect was measured on the basis of a ratings 1 to 5 ( 1 = Excellent, $2=$ Very Good, $3=$ Good, 4 = Fairly Good, 5 = Not Good). Grain yield per plot was determined at $14 \%$ moisture content from which grain yield per ha was estimated [34].

\subsection{Statistical Analyzes}

Analysis of variance (ANOVA) using linear model $=\operatorname{aov}(\mathrm{Y} \sim$ trait $\sec \times$ trait princ + Error (Repetition/trait princ)) of R packages with the LSD test were used to determine differences between treatments. In addition, a principal component analysis (PCA) was carried out to detect the similarities between the factors according to the variables that characterize them.

\section{Results and Discussion}

\subsection{Effects of Seeding Densities and Smaller Mineral Fertilizer Rates on MUDISHI 1 Growth Parameters}

According to the applied fertilizer rates, the results showed that the emergence rate decreases with the addition of fertilizer. The average vegetative performance is presented in Table 3. The analysis of variance showed that only two vegetative parameters were influenced by the fertilizer rate: the rates of emergence and collar diameter. Indeed, the best performing emergence rate was obtained with the high density $\left(106,666\right.$ plants.ha $\left.{ }^{-1}\right)$ at D3 while the biggest collar diameter was recorded at all densities at D4. However, no significant difference $(p>0.05)$ was observed for the other vegetative parameters. This supports [35] and [12] who reported that seeding density is less affecting the vegetative cycle of maize. This explains the lack of difference of days to flowering. Similar results were obtained by [36] in a study aimed to evaluate the effects of seeding density.

\subsection{Effects of Planting Density and Smaller Mineral Fertilizer Rates on MUDISHI-1 Yield Parameters}

The average yield parameters performances are summarized in Table 4. Data analysis showed that planting densities influenced the yield and the harvest rate. However the fertilizer rates influenced all yield parameters. Higher yields were obtained with the double planting density when using D4 and D3 rates according to [18]. Indeed, the double planting density resulted in higher grain yield $\left(6.05 \mathrm{t} \cdot \mathrm{ha}^{-1}\right)$ followed by the one of 53,333 plants $\cdot \mathrm{ha}^{-1}\left(4.94 \mathrm{t} \cdot \mathrm{ha}^{-1}\right)$ while the farmer's planting density got the lowest yield $\left(3.60 \mathrm{t} \cdot \mathrm{ha}^{-1}\right)$ when $\mathrm{D} 4$ was applied. The double planting density highest yield $\left(6.05 \mathrm{t} \cdot \mathrm{ha}^{-1}\right)$ obtained during this study 
Table 3. Average vegetative performance of Mudishi-1 in Mvuazi conditions.

\begin{tabular}{|c|c|c|c|c|c|}
\hline Treatments & Plant.asp (1 - 5) & Collar.diam (mm) & Plant height $(\mathrm{cm})$ & Pollen (days) & Emergence rate (\%) \\
\hline $0.75 \mathrm{~m} \times 0.25 \mathrm{~m}: \mathrm{D} 1$ & $1.00 \pm 0 \mathrm{a}$ & $14.80 \pm 0.46 \mathrm{~d}$ & $244.66 \pm 47.34 \mathrm{a}$ & $54.66 \pm 1.52 \mathrm{ab}$ & $77.88 \pm 7.63 a$ \\
\hline $0.75 \mathrm{~m} \times 0.25 \mathrm{~m}: \mathrm{D} 2$ & $1.33 \pm 0.57 \mathrm{a}$ & $18.23 \pm 0.44 b c$ & $259.66 \pm 21.36 \mathrm{a}$ & $55.00 \pm 1.73 \mathrm{ab}$ & $50.96 \pm 31.20 \mathrm{bc}$ \\
\hline $0.75 \mathrm{~m} \times 0.25 \mathrm{~m}: \mathrm{D} 3$ & $1.00 \pm 0 \mathrm{a}$ & $20.17 \pm 1.54 \mathrm{ab}$ & $272.00 \pm 0 \mathrm{a}$ & $54.00 \pm 1.73 \mathrm{ab}$ & $78.84 \pm 5.35 \mathrm{a}$ \\
\hline $0.75 \mathrm{~m} \times 0.25 \mathrm{~m}: \mathrm{D} 4$ & $1.00 \pm 0 \mathrm{a}$ & $20.28 \pm 2.18 \mathrm{ab}$ & $272.00 \pm 0 \mathrm{a}$ & $53.00 \pm 0 b$ & $66.34 \pm 6.93$ \\
\hline $0.75 \mathrm{~m} \times 0.50 \mathrm{~m}: \mathrm{D} 1$ & $1.00 \pm 0 \mathrm{a}$ & $13.45 \pm 0.78 \mathrm{~d}$ & $243.00 \pm 50.22 \mathrm{a}$ & $53.33 \pm 0.57 b$ & $62.96 \pm 1.85 \mathrm{abc}$ \\
\hline $0.75 \mathrm{~m} \times 0.50 \mathrm{~m}: \mathrm{D} 2$ & $1.33 \pm 0.57 a$ & $19.14 \pm 1.67 \mathrm{abc}$ & $257.66 \pm 24.82 \mathrm{a}$ & $56.00 \pm 0 \mathrm{a}$ & $41.29 \pm 21.39 c$ \\
\hline $0.75 \mathrm{~m} \times 0.50 \mathrm{~m}: \mathrm{D} 3$ & $1.33 \pm 0.57 \mathrm{a}$ & $19.05 \pm 0.57 \mathrm{abc}$ & $260.06 \pm 20.66 a$ & $54.00 \pm 1.73 \mathrm{ab}$ & $70.37 \pm 3.20 \mathrm{ab}$ \\
\hline $0.75 \mathrm{~m} \times 0.50 \mathrm{~m}: \mathrm{D} 4$ & $1.33 \pm 0.57 \mathrm{a}$ & $20.20 \pm 2.23 \mathrm{ab}$ & $272.00 \pm 0 \mathrm{a}$ & $54.00 \pm 1.73 \mathrm{ab}$ & $65.43 \pm 2.13 \mathrm{ab}$ \\
\hline $1 \mathrm{~m} \times 1 \mathrm{~m}: \mathrm{D} 1$ & $1.33 \pm 0.57 \mathrm{a}$ & $14.78 \pm 1.52 \mathrm{~d}$ & $244.53 \pm 47.57 a$ & $55.00 \pm 1.73 \mathrm{ab}$ & $68.75 \pm 3.12 \mathrm{ab}$ \\
\hline $1 \mathrm{~m} \times 1 \mathrm{~m}: \mathrm{D} 2$ & $1.66 \pm 0.57 \mathrm{a}$ & $17.56 \pm 0.99 c$ & $250.33 \pm 37.57 a$ & $55.00 \pm 1.73 \mathrm{ab}$ & $51.04 \pm 15.72 b c$ \\
\hline $1 \mathrm{~m} \times 1 \mathrm{~m}: \mathrm{D} 3$ & $1.33 \pm 0.57 \mathrm{a}$ & $19.29 \pm 0.08 \mathrm{abc}$ & $257.40 \pm 25.28 \mathrm{a}$ & $54.00 \pm 1.73 \mathrm{ab}$ & $70.83 \pm 3.60 \mathrm{ab}$ \\
\hline $1 \mathrm{~m} \times 1 \mathrm{~m}: \mathrm{D} 4$ & $1.00 \pm 0 \mathrm{a}$ & $20.89 \pm 1.95 a$ & $272.00 \pm 0 \mathrm{a}$ & $54.00 \pm 1.73 \mathrm{ab}$ & $55.20 \pm 21.27 b c$ \\
\hline Density & 0.386 & 0.782 & 0.804539 & 0.867 & 0.25952 \\
\hline Dose.of.fertil & 0.355 & $2.27 \mathrm{e}-08^{\star * *}$ & 0.087654 & 0.140 & $0.00207^{\star}$ \\
\hline Density: Dose.of.fertil & 0.366 & 0.985 & 0.996259 & 1.000 & 0.06895 \\
\hline CV (\%) & 36.19 & 7.8 & 8.71 & 2.8 & 20.78 \\
\hline LSD (0.05) & 0.74 & 2.41 & 38.11 & 2.57 & 22.22 \\
\hline
\end{tabular}

Signif. codes: 0 “***” 0.001 “**” 0.01 “*” 0.05 “.” 0.1 “” 1 . The different letters indicate significant differences and the same letters, non-significant differences after comparison of means by the LSD test $(\mathrm{p}<0.05)$.

Table 4. Average yield components performance of MUDISHI-1 in Mvuazi conditions.

\begin{tabular}{|c|c|c|c|c|c|}
\hline Treatments & Yield (t/ha) & ear.asp $(1-5)$ & Ear.diam $(\mathrm{mm})$ & Ear.lengh (cm) & Harvest.rate (\%) \\
\hline $0.75 \mathrm{~m} \times 0.25 \mathrm{~m}: \mathrm{D} 1$ & $2.69 \pm 0.6 \mathrm{de}$ & $2.33 \pm 0.57 \mathrm{ab}$ & $49.70 \pm 2.11 \mathrm{bcd}$ & $17.21 \pm 0.58 b c$ & $55.50 \pm 11.14 \mathrm{~d}$ \\
\hline $0.75 \mathrm{~m} \times 0.25 \mathrm{~m}: \mathrm{D} 2$ & $4.13 \pm 0.43 b c$ & $1.33 \pm 0.57 c$ & $48.55 \pm 2.21 \mathrm{~cd}$ & $17.66 \pm 1.85 \mathrm{abc}$ & $79.55 \pm 19.46 \mathrm{abc}$ \\
\hline $0.75 \mathrm{~m} \times 0.25 \mathrm{~m}: \mathrm{D} 3$ & $5.65 \pm 1.66 \mathrm{a}$ & $1.00 \pm 0 c$ & $51.99 \pm 1.39 \mathrm{abc}$ & $17.33 \pm 0.44 b c$ & $70.14 \pm 5.69 c d$ \\
\hline $0.75 \mathrm{~m} \times 0.25 \mathrm{~m}: \mathrm{D} 4$ & $6.05 \pm 0.57 \mathrm{a}$ & $1.00 \pm 0 c$ & $51.65 \pm 1.09 \mathrm{abc}$ & $19.16 \pm 0.72 a$ & $76.63 \pm 2.55 b c$ \\
\hline $0.75 \mathrm{~m} \times 0.50 \mathrm{~m}: \mathrm{D} 1$ & $1.91 \pm 0.74 \mathrm{e}$ & $2.66 \pm 1.15 \mathrm{a}$ & $46.86 \pm 4.96 \mathrm{~d}$ & $15.39 \pm 2.90 \mathrm{~d}$ & $69.64 \pm 2.70 \mathrm{~cd}$ \\
\hline $0.75 \mathrm{~m} \times 0.50 \mathrm{~m}: \mathrm{D} 2$ & $3.44 \pm 0.25 c d$ & $1.00 \pm 0 c$ & $52.29 \pm 2.33 \mathrm{ab}$ & $18.44 \pm 0.97 \mathrm{ab}$ & $90.10 \pm 10.31 \mathrm{ab}$ \\
\hline $0.75 \mathrm{~m} \times 0.50 \mathrm{~m}: \mathrm{D} 3$ & $3.74 \pm 1.10 \mathrm{bcd}$ & $1.00 \pm 0 c$ & $50.90 \pm 2.85 \mathrm{abc}$ & $18.55 \pm 0.75 \mathrm{ab}$ & $78.20 \pm 12.36 \mathrm{abc}$ \\
\hline $0.75 \mathrm{~m} \times 0.50 \mathrm{~m}: \mathrm{D} 4$ & $4.94 \pm 0.87 \mathrm{ab}$ & $1.00 \pm 0 c$ & $53.66 \pm 1.65 \mathrm{a}$ & $18.71 \pm 1.08 \mathrm{ab}$ & $91.44 \pm 5.01 \mathrm{ab}$ \\
\hline $1 \mathrm{~m} \times 1 \mathrm{~m}: \mathrm{D} 1$ & $2.90 \pm 1.07 \mathrm{cde}$ & $1.66 \pm 0.57 \mathrm{bc}$ & $49.34 \pm 1.67 \mathrm{bcd}$ & $16.61 \pm 0.34 \mathrm{~cd}$ & $78.68 \pm 7.47 \mathrm{abc}$ \\
\hline $1 \mathrm{~m} \times 1 \mathrm{~m}: \mathrm{D} 2$ & $3.02 \pm 0.61 \mathrm{cde}$ & $1.00 \pm 0 c$ & $51.20 \pm 1.41 \mathrm{abc}$ & $19.27 \pm 1.41 \mathrm{a}$ & $86.64 \pm 19.15 \mathrm{abc}$ \\
\hline $1 \mathrm{~m} \times 1 \mathrm{~m}: \mathrm{D} 3$ & $3.68 \pm 0.38 \mathrm{bcd}$ & $1.00 \pm 0 \mathrm{c}$ & $51.34 \pm 1.29 \mathrm{abc}$ & $18.10 \pm 0.94 \mathrm{abc}$ & $95.584 .55 \mathrm{a}$ \\
\hline $1 \mathrm{~m} \times 1 \mathrm{~m}: \mathrm{D} 4$ & $3.60 \pm 1.22 \mathrm{~cd}$ & $1.00 \pm 0 c$ & $54.52 \pm 1.01 \mathrm{a}$ & $18.83 \pm 0.28 \mathrm{ab}$ & $95.21 \pm 5.01 \mathrm{a}$ \\
\hline Density & $0.000471^{\star * *}$ & 0.298 & 0.45696 & 0.562822 & $0.00104^{\star *}$ \\
\hline Dose.of.fertil & $4.91 \mathrm{e}-06^{* * *}$ & $6.8 \mathrm{e}-06^{\star * *}$ & $0.00173^{* *}$ & $0.000234^{* * *}$ & $0.00292^{\star *}$ \\
\hline Density: Dose.of.fertil & 0.070817 & 0.398 & 0.21538 & 0.194100 & 0.66667 \\
\hline $\mathrm{CV}$ & 19.71 & 33.17 & 4.28 & 5.80 & 13.18 \\
\hline LSD & 1.271551 & 0.74 & 3.69 & 1.76 & 17.95 \\
\hline
\end{tabular}

Signif. codes: 0 “***” 0.001 “**” 0.01 “*” 0.05 “.” 0.1 “” 1 . The different letters indicate significant differences and the same letters, non-significant differences after comparison of means by the LSD test $(\mathrm{p}<0.05)$. 
is equivalent to that obtained in forest soil without fertilizers in Lomami province under farmers' conditions (40,000 plants.ha ${ }^{-1}$ ). In this soil type, the double planting density could allow higher yields for farmers if properly used. Under D3 dose, the double planting density once more recorded the highest yield (5.65 $\mathrm{t} \cdot \mathrm{ha}^{-1}$ ), which the 53,333 plants.ha ${ }^{-1}$ seeding density have not even reached under D4. At the same rate (D3), the two others got similar yields (3.74 and $3.68 \mathrm{t} \cdot \mathrm{ha}^{-1}$ respectively for 53,333 and 40,000, plants $\cdot \mathrm{ha}^{-1}$ ). This means, higher planting densities like the double planting density is a high potential yield practice compared with the lower densities when the applied fertilizers dose is adequate. This supports [37] who found that the number of plants per unit area is the most important component of yield because if there are not enough plants, a high number of ears per unit area and yield cannot be expected. [38] estimated that the high yield of maize on high density plots is generally due to the high number of ears per row and the high number of rows of seeds per ear. In addition, despite competition between plants on high density plots [39] and nutrient competition [40], the yield obtained is the sum of individual productions. The high yield obtained on high density plots is thus justified by the optimization of the use of the soil and environmental resources by the crop. However, under D2 all yields were similar for all planting densities. The same trend was observed for D1 but with the lowest yields recorded similarly to [4] results. This means that when fertilizers are not applied at all, low planting density yields better. It is then advisable to go for it in this case as higher planting densities are time consuming, more laborious and backbreaking at holes digging and planting time.

\subsection{Principal Component Analysis (PCA)}

Among twelve dimensions generated by the PCA, only the first four dimensions had an eigenvalue greater than one (Table 5).

Figure 2 shows the contribution of 9 variables to the first and second axes of the principal component analysis (47.39\% of the total variation). Ear length, ear diameter, plant height, harvest percentage, collar diameter, and yield have strong and positive contributions to Dim1. These variables also have a strong correlation between them. These contributions are also stronger but negative for the ears aspect on Dim1. On the other hand, yield, emergence rate, flowering, plant aspect are the variables having a higher contribution on Dim2. The Dim2 thus represents production better because all the variables relating to this phase of the life cycle measured in this study have the greatest contributions on this axis. Similarly, the Dim1 better represents the parameters of the growth.

Based on the contributions of the variables on Dim1 (Figure 2), it seems that D1 leads to low values of growth and low, according to [4] and [5]. On the other hand, the double dose (D4) and single dose and half (D3), lead to high values of yield and growth parameters [23]. However D2 leads to low values of yield and high values of growth. The high density $(0.75 \mathrm{~m} \times 0.25 \mathrm{~m}$ with 2 grains/hill) with a high contribution in Dim3 leads to high values of yields. 
Variables factor map (PCA)

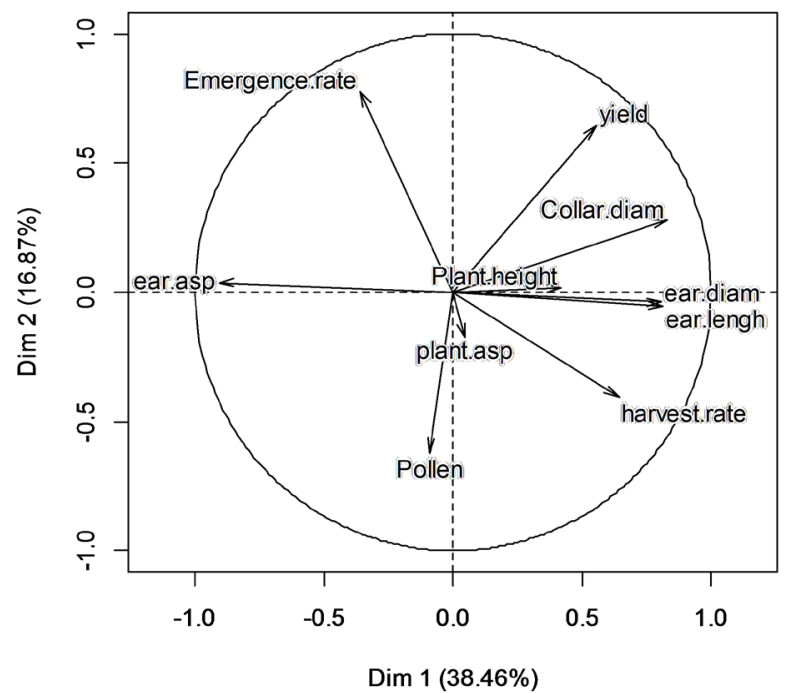

Individuals factor map (PCA)

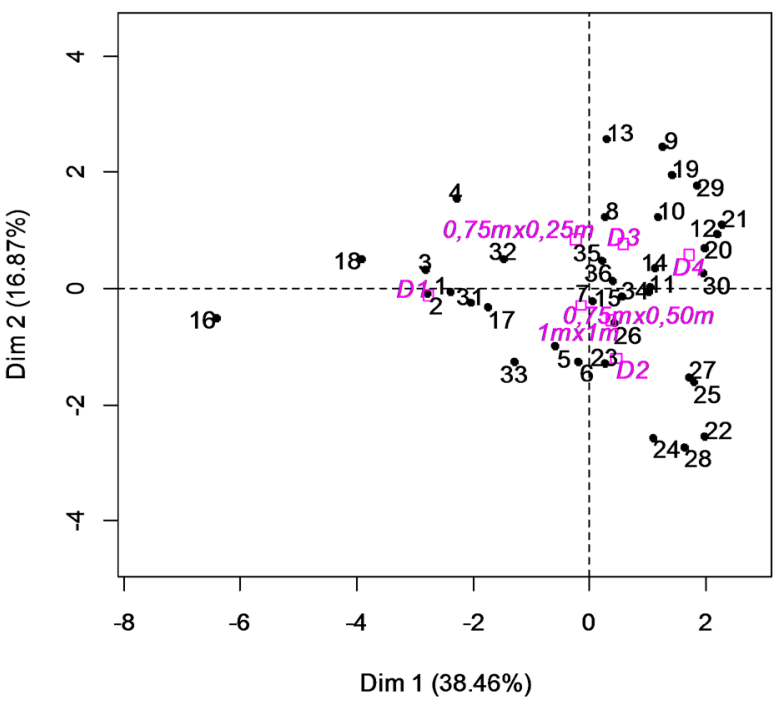

Figure 2. PCA Individuals factor map and variables factors map: yield, emergence rate, ear aspect, collar diameter, ear diameter, ear length, flowering day, harvest rate, plant appearance and plant height.

Table 5. Eigenvalues, variance percentage change, and percentage of cumulative changes.

\begin{tabular}{ccccc}
\hline Eigenvalue & Dim.1 & Dim.2 & Dim.3 & Dim.4 \\
\hline Variance & 3.944 & 1.744 & 1.489 & 1.206 \\
\% of var. & 32.863 & 14.532 & 12.412 & 10.054 \\
Cumulative \% of var. & 32.863 & 47.396 & 59.808 & 69.862 \\
\hline
\end{tabular}

\section{Conclusion}

This study is a contribution to the improvement of maize production, in a context where mineral fertilizers are high-priced and proved improved cultural practices unused despite their handiness. Four mineral fertilizers doses (D1, D2, D3 and D4) and three seeding densities (40,000, 53,333 and 106,666 plants.t.ha $\left.{ }^{-1}\right)$ were assessed in order to contribute to the food security, through the intensification of maize cultivation for the populations living in Mvuazi agricultural zone. The results obtained showed that the seeding density did not affect most of the studied parameters, except collar diameter and yield. The double planting density $\left(106,666\right.$ plants.ha $\left.{ }^{-1}\right)$ resulted in higher grain yield $\left(6.05 \mathrm{t} \cdot \mathrm{ha}^{-1}\right)$ and 5.65 t.ha ${ }^{-1}$ when the highest fertilizer rates (D4 and D3 respectively) are applied. It out-yielded the farmer's planting density by $40 \%$ and $36 \%$ respectively. Under D1 (no fertilizers application), yields obtained were the lowest but similar regardless of planting densities. In conclusion, the double planting density and the application of D3 and D4 micro doses combined with localized placement have been found adequate and more performing and hence recommendable for intensification of maize cultivation in Mvuazi. In addition, in a situation where fertilizers are not applied, it is advisable to go for lower planting density (farmer's 
seeding density) as manual higher planting densities are time consuming, more laborious and backbreaking at holes digging and planting time.

\section{Conflicts of Interest}

The authors declare no conflicts of interest regarding the publication of this paper.

\section{References}

[1] SENASEM (2008) Variety Catalog of Food Crops: Cereals (Maize, Rice), Legumes (Beans, Soybeans, Cowpeas), Tuber Crops (Cassava, Sweet Potato, Potato), Banana. Support of the BTC/MINAGRI Project, Kinshasa, 153.

[2] Anonymous (2009) Agricultural Sector Study: Preliminary Report, Diagnostic Assessment and Guidance Notes. National Ministry of Agriculture Fisheries and Livestock, Tecsul and EGTC, Kinshasa, DRC. 337 p.

[3] FAOSTAT (2013). http://FAOSTAT.fao.org/default.aspx?Ali==FAOSTAT\&lang=en

[4] LAw-Ogbomo, K. and Remison, S.U. (2008) Growth and Yield of White Guinea Yam (Dioscorea rotundata Poir) Influenced by NPK Fertilization on a Forest Site of Nigeria. Journal of Tropical Agriculture, 46, 9-12.

[5] Fakorede, M.A.B., Badu-Apraku, N., Coulibaly, O. and Fajemisin, J.M. (2001) Maize Research and Development Priorities in Sub-Saharan African in the Next Millennium. Proceedings of a Regional Maize Workshop, Cotonou, 4-7 May 1999, 31-58.

[6] Tahir, M., Javed, M.R., Tanveer, A., Nadeemm, A., Wasaya, A., Bukhari, S.A.H. and Rehman, J.U. (2009) Effect of Different Herbicides on Weeds, Growth and Yield of Spring Planted Maize (Zea mays L.). Pakistan Journal of Life and Social Sciences, 7, 168-174.

[7] Sallah, P.Y.K., Nkerabahizi, D., Ndayiragije, A., Ndiramiye, L., Night, G., Akinyemi, S.O.S. and Kanuya, N. (2007) Diagnostic Survey of the Farming Systems in Rusogo Watershed in Nyabihu District of Rwanda: Cropping Systems and Challenges. In Proc. of National conference on Agricultural Research Output (Editor: Njeru et al.). 26-27 March 2007, Serena Hotel, Kigali, Rwanda.

[8] Sallah, P.Y.K., Mukakalisa, S., Nyombayire, A. and Mutanyagwa, P. (2009) Responses of Two Maize Varieties in the Highland Zone of Rwanda. Journal of Applied Biosciences, 20, 1194-1202.

[9] Lui, S. (2000) Understanding Plant Density Effects on Maize Growth and Development: An Important Issue to Maximize Grain Yield. Ciência Rural, Santa maria, 31, 159-168. https://doi.org/10.1590/S0103-84782001000100027

[10] Esechi, H.A. (1992) Effect of Planting Density on Growth and Yield of Irrigated Maize in the Batinah Coast Region of Oman. The Journal of Agricultural Science, 119, 165-169. https://doi.org/10.1017/S0021859600014076

[11] Akbar, H., Miftahullah, M.T., Jan, A. and Ihsanullah, A. (2002) Yield Potential of Sweet Corn by Different Levels of Nitrogen and Plant Population. Asian Journal of Plant Sciences, 1, 631-633. https://doi.org/10.3923/ajps.2002.631.633

[12] Muoneke, C.O., Mao, O. and Bakul, B.A. (2007) Effect of Maize Planting Density on the Performance of Maize/Soybean Intercropping System in a Savannah Agroecosystem. African Journal of Agricultural Research, 2, 667-677.

[13] Abuzar, M.R., Sadozai, G.U., Baloch, M.S., Baloch, A.A., Shah, I.H., Javaid, T. and 
Hussain, N. (2011) Effect of Plant Population Densities on Yield of Maize. The Journal of Animal \& Plant Sciences, 21, 692-695.

[14] Shafi, M., Jehan, B., Sajjad, A., Hamayoon, K., Mohammad, A.K. and Mohammad, S. (2012) Effect of Planting Density on Phenology, Growth and Yield of Maize (Zea mays L.). Pakistan Journal of Botany, 44, 691-696.

[15] Carlone, M.R. and Russell, W.A. (1987) Response to Plant Densities and Nitrogen Levels for Four Maize Cultivars from Different Eras of Breeding. Crop Science, 27, 465-470. https://doi.org/10.2135/cropsci1987.0011183X002700030008x

[16] Shrestha, J., Yadav, D.N., et al. (2018) Effects of Nitrogen and Plant Density on Maize (Zea mays L.) Phenology and Grain Yield. Current Agriculture Research Journal, 6, 175-182. https://doi.org/10.12944/CARJ.6.2.06

[17] Sharma, K.C. and Gupta, P.C. (1968) Effect of Plant Population Densities and Rates of Nitrogen on the Performance of Hybrid Maize. Indian Journal of Agronomy, 13, 76-82.

[18] Tokatlidis, I.S., Has, V., Melidis, V., Has, I. and Mylonas, I. (2011) Maize Hybrids Less Dependent on High Plant Densities Improve Resource-Use Efficiency in Rain Fed and Irrigated Conditions. Field Crops Research, 120, 345-351. https://doi.org/10.1016/j.fcr.2010.11.006

[19] Tollenaar, M. (1989) Genetic Improvement in Grain Yield of Commercial Maize Hybrids Grown in Ontario from 1959 to 1988. Crop Science, 29, 1365-1371. https://doi.org/10.2135/cropsci1989.0011183X002900060007x

[20] Echarte, L., Luque, S., Andrade, F.H., Sadras, V.O., Cirilo, A., Otegui, M.E. and Vega, C.R.C. (2000) Response of Maize Kernel Number to Plant Density in Argentinean Hybrids Released between 1965 and 1993. Field Crops Research, 68, 1-8. https://doi.org/10.1016/S0378-4290(00)00101-5

[21] Duvick, D.N. (2005) Genetic Progress in Yield of United States Maize (Zea mays L.). Maydica, 50, 193-202.

[22] Rossini, M.A., Maddonni, G.A. and Otegui, M.E. (2011) Inter-Plant Competition for Resources in Maize Crops Grown under Contrasting Nitrogen Supply and Density: Variability in Plant and Ear Growth. Field Crops Research, 121, 373-380. https://doi.org/10.1016/j.fcr.2011.01.003

[23] Duvick, D.N. (2015) The Contribution of Breeding to Yield Advances in Maize (Zea mays L.). Advances in Agronomy, 86, 83-145. https://doi.org/10.1016/S0065-2113(05)86002-X

[24] Wu, Y.C., Ma, Z.Y., Wang, D.Y. and Jiang, J. (1998) Analyses of Contribution of Maize Improvement to Yield Increment in China. Acta Agronomica Sinica, 24, 593-600.

[25] Ma, B.L., Soubedi, K.D. and Liu, A. (2006) Variations in Grain Nitrogen Removal Associated with Management Practices in Maize Production. Nutrient Cycling in Agroecosystems, 76, 67-80. https://doi.org/10.1007/s10705-006-9041-y

[26] Tokatlidis, I.S. and Koutroubas, S.D. (2004) A Review of Maize Hybrids' Dependence on High Plant Populations and Its Implications for Crop Yield Stability. Field Crops Research, 88, 103-114. https://doi.org/10.1016/j.fcr.2003.11.013

[27] Antoniatta, M., Fanello, D.D., Acciaresi, H.A. and Guiamet, J.J. (2014) Senescence and Yield Responses to Plant Density in Stay Green and Earlier Senescing Maize Hybrids from Argentina. Field Crops Research, 155, 111-119.

https://doi.org/10.1016/j.fcr.2013.09.016 
[28] Testa, G., Reyneri, A. and Blandino, M. (2016) Maize Grain Yield Enhancement through High Plant Density Cultivation with Different Inter-Row and Intra-Row Spacings. European Journal of Agronomy, 72, 28-37. https://doi.org/10.1016/j.eja.2015.09.006

[29] Hodgen, P. (2007) Individual Corn Plant Nitrogen Management. PhD Dissertation, University of Nebraska, Lincoln.

[30] Yan, P., Pan, J., Zhang, W., Shi, J., Chen, X. and Cui, Z. (2017) A High Plant Density Reduces the Ability of Maize to Use Soil Nitrogen. PLoS ONE, 12, e0172717. https://doi.org/10.1371/journal.pone.0172717

[31] Tollenaar, M., Deen, W., Echarte, L. and Liu, W. (2006) Effect of Crowding Stress on Dry Matter Accumulation and Harvest Index in Maize. Agronomy Journal, 98, 930-937. https://doi.org/10.2134/agronj2005.0336

[32] Köppe, W. (1936) Das geographische System der Klimate. In: Köppe, W. and Geiger, H., Eds., Handbuch der Klimatologie, Gebrüder Borntraeger, Berlin, 1-44.

[33] Kabongo, T., Pongi, K. Mumba, J., Mbuya, K., Kizungu, V. and Kabwe, K. (2016) Evaluation of Maize Sensitivity in Southwestern Savannah Area of DR-Congo. African Journal of Agricultural Science and Technology, 4, 812-817.

[34] Mbuya, K., Nkongolo, K.K., Narendrula, R., Kalonji-Mbuyi, A. and Kizungu, R.V. (2010) Participatory Selection and Characterization of Quality Protein Maize (QPM) Varieties in Savanna Agroecological Region of DR-Congo. Journal of Plant Breeding and Crop Science, 2, 325-332.

[35] Hassan, A.E. (1987) Performance of Three Corn Cultivars (Zea mays L.) as Affected by Plant Density in Riyadh Region. Arab Gulf Journal of Scientific Research, 5, 199-203.

[36] Yannick, U.S., Alain, M.L., et al. (2014) Does the Contribution of Low Doses of Mineral Fertilizer Increase the Yield of High-Density Corn? An Example with Two Maize Varieties in Lubumbashi. Journal of Applied Biosciences, 74, 6131-6140. https://doi.org/10.4314/jab.v74i1.4

[37] Mandić, V., Bijelić, Z., Krnjaja, V., Tomić, Z., Stanojković-Sebić, A., et al. (2016) The Effect of Crop Density on Maize Grain Yield. Biotechnology in Animal Husbandry, 32, 83-90. https://doi.org/10.2298/BAH1601083M

[38] Eman, Y. (2001) Sensitivity of Grain Yield Components to Plate Population Density in Non-Prolific Maize (Zea mays) Hybrids. Indian Journal of Agricultural Science, 71, 367-370.

[39] Zamir, M.S.I., Ahmad, A.H., Javeed, H.M.R. and Latif, T. (2011) Growth and Yield Behavior of Two Maize Hybrids (Zea mays L.) towards Different Plant Spacing. Cercetari Agronomie în Moldova, 14, 33-40. https://doi.org/10.2478/v10298-012-0030-9

[40] Sangakkara, U.R., Bandaranayake, P.S.R.D., Gajanayake, J.N. and Stamp, P. (2004) Plant Populations and Yield of Rainfed Maize Grown in Wet and Dry Seasons of the Tropics. Maydica, 49, 83-88. 